\title{
Sex-specific lung diseases: effect of oestrogen on cultured cells and in animal models
}

\author{
Bosung Shim', Gustavo Pacheco-Rodriguez, Jiro Kato1, Thomas N. Darling², \\ Martha Vaughan ${ }^{1}$ and Joel Moss ${ }^{1}$
}

Affiliations: ${ }^{1}$ Cardiovascular and Pulmonary Branch, National Heart, Lung, and Blood Institute, National Institutes of Health, Bethesda, MD, and ${ }^{2}$ Dept of Dermatology, Uniformed Services University of the Health Sciences, Bethesda, MD, USA.

Correspondence: J. Moss, Cardiovascular and Pulmonary Branch, National Heart, Lung, and Blood Institute, National Institutes of Health, Bldg.10/Room 6D05/MSC-1590, Bethesda, MD, USA, 2089-1590. E-mail: mossjanhlbi.nih.gov

ABSTRACT Sex prevalence in lung disease suggests that sex-specific hormones may contribute to the pathogenesis and/or progression of at least some lung diseases, such as lung adenocarcinoma, lymphangioleiomyomatosis (LAM) and benign metastasising leiomyoma (BML). Oestrogen is an important hormone in normal lung development and in the pathogenesis of female predominant pulmonary diseases. In vivo and in vitro studies have facilitated our understanding of disease pathogenesis and discovery of potential therapeutic targets. Oestrogen promoted disease progression in cell and animal models of lung adenocarcinoma, LAM and BML. Specifically, oestrogen enhanced tumour growth and metastasis in animal models of these diseases. Furthermore, $17 \beta$-estradiol $\left(\mathrm{E}_{2}\right)$, the most abundant form of oestrogen in humans, increased the size and proliferation of cultured cells of lung adenocarcinoma and LAM. Coupled with the known mechanisms of oestrogen metabolism and signalling, these model systems may provide insights into the diverse effects of oestrogen and other hormones on lung diseases. Anti-oestrogen treatments that target key events of oestrogen synthesis or signalling, such as aromatase activity, oestrogen receptors and signalling pathways, may offer additional opportunities for clinical trials.

0

@ERSpublications

Research shows oestrogen promotes progression of female-prevalent lung diseases such as adenocarcinoma, LAM and BML http://ow.ly/mRLfI

\section{Introduction}

Sex differences in lung disease populations suggest that sex-specific hormones, e.g. oestrogen, play a role in disease pathogenesis (table 1, fig. 1) [1-12]. Asthma, one of the most common lung diseases, is diagnosed more frequently in males than females before puberty. However, asthma is diagnosed more frequently in adult females [13-15]. Chronic obstructive pulmonary disease (COPD), once considered a disease of males, is increasingly prevalent among females; in contrast, the proportion of males diagnosed with COPD appears to have plateaued or decreased $[16,17]$. Female prevalence of COPD has been associated with the increased use of tobacco $[18,19]$. The increase of tobacco-related lung cancer appears to parallel the incidence of COPD in females [20].

Received: May 082013 | Accepted after revision: June 172013

Support Statement: This publication was supported by the Intramural Research Program, National Institutes of Health (NIH), National Heart, Lung, and Blood Institute (NHLBI), Bethesda, MD, USA.

Conflict of interest: None declared.

Provenance: Publication of this peer-reviewed article was supported by the World Scleroderma Foundation, Switzerland (principal sponsor, European Respiratory Review issue 129). 
TABLE 1 Sex prevalence in lung diseases

\begin{tabular}{|c|c|c|c|c|}
\hline Pulmonary disease & First author [ref.] & Subjects $\mathrm{n}$ & Male:female ratio & Females \% \\
\hline LAM & RYu [1] & 230 & $0: 230$ & 100 \\
\hline BML & PITTS [2] & 100 & $0: 100$ & 100 \\
\hline Lung adenocarcinoma & Muscat [3] & 337 & $69: 126$ & 65 \\
\hline PAH & BADESCH [4] & 1166 & $230: 936$ & 80 \\
\hline CT-ILD & Cottin [5] & 34 & $10: 24$ & 70 \\
\hline \multirow[t]{2}{*}{ IPF } & GRIBBIN [6] & 920 & $568: 352$ & 38 \\
\hline & BAUMGARTNER [7] & 248 & $149: 99$ & 40 \\
\hline \multirow[t]{2}{*}{ ILD } & KoRnUm [8] & 21765 & $12639: 9126$ & 42 \\
\hline & COULTAS [9] & 258 & $136: 122$ & 47 \\
\hline PLCH & VASSALLO [10] & 102 & $40: 62$ & 61 \\
\hline \multirow[t]{2}{*}{ NSIP } & TRAVIS [11] & 67 & $22: 45$ & 67 \\
\hline & TRAVIS [11] & 386 & $189: 197$ & 51 \\
\hline RB-ILD & PoRtnoy [12] & 32 & 15:17 & 53 \\
\hline
\end{tabular}

LAM: lymphangioleiomyomatosis; BML: benign metastasising leiomyoma; PAH: pulmonary arterial hypertension; CT-ILD: connective tissue-associated interstitial lung disease; ILD: interstitial lung disease; PLCH: pulmonary Langerhans' cell histiocytosis; NSIP: nonspecific interstitial pneumonia; RB-ILD: respiratory bronchiolitis-associated interstitial lung disease.

Although sex specificity of some lung diseases is apparent, the lack of comprehensive studies and epidemiological data poses a major challenge in determining sex differences in disease populations. Both lymphangioleiomyomatosis (LAM) and benign metastasising leiomyoma (BML) have been primarily diagnosed in females and, thus, female hormones seem likely to contribute to disease progression $[1,2]$. In agreement, there are only a few isolated case reports that document the occurrence of clinically significant LAM in males [21, 22]. Female predominance was also apparent in lung adenocarcinoma [3], pulmonary arterial hypertension [4] and connective tissue-associated interstitial lung disease (ILD) [5], whereas male predominance was observed in idiopathic pulmonary fibrosis [6,7]. Evidence of sex predominance is inconclusive for ILD [8,9], pulmonary Langerhans' cell histiocytosis [10], nonspecific interstitial pneumonia [11], and respiratory bronchiolitis-associated ILD [12]. Potential contributions of oestrogen to disease pathogenesis may be better assessed through additional research using model systems.

Cultured cells and animal models can be valuable for exploration of disease pathogenesis, progression and underlying mechanisms. Cultured cells are often used to elucidate the biochemical mechanisms that dictate physiological phenomena in lung diseases, as well as to evaluate effects of endogenous or exogenous oestrogen on cellular biology. Experimental small animals, particularly rats and mice, are frequently used as models to investigate human lung physiology and pathophysiology. Methodologies for experimentally altering oestrogen levels either surgically (e.g. ovariectomy) or chemically (e.g. gonadotropin-releasing hormone agonists or oestrogen inhibitors) can provide important insights into sex effects on lung diseases.

FIGURE 1 Sex prevalence among adults with lung disease. LAM: lymphangioleiomyomatosis; BML: benign metastasising leiomyoma; AdC: lung adenocarcinoma; PAH: pulmonary arterial hypertension; CT-ILD: connective tissue-associated interstitial lung disease; IPF: idiopathic pulmonary fibrosis; ILD: interstitial lung disease; PLCH: pulmonary Langerhans' cell histiocytosis; NSIP: nonspecific interstitial pneumonia; RB-ILD: respiratory bronchiolitis-associated interstitial lung disease. - - - -: 50:50 female:male ratio.

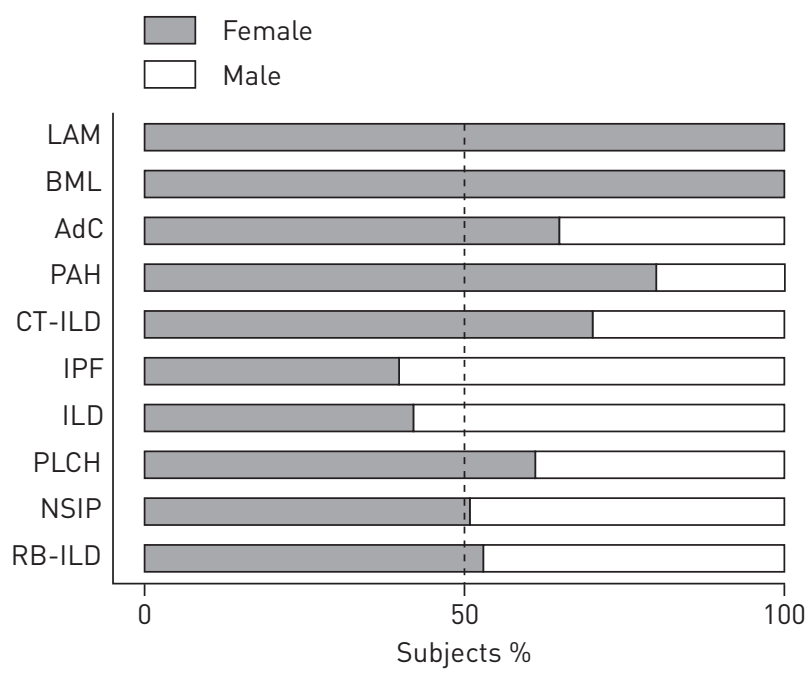




\section{Oestrogen metabolism and signalling in lung diseases}

Oestrogen, a female hormone that is important in normal lung development, enhances growth of femalespecific tumours, such as breast cancer and endometrial adenocarcinoma [23, 24]. 17 $\beta$-estradiol $\left(\mathrm{E}_{2}\right)$, the most abundant form of oestrogen in females, and other steroid hormones are synthesised from cholesterol [25]. Aromatase (CYP19) is a cytochrome P-450 enzyme that catalyses the rate-limiting conversion of testosterone to $\mathrm{E}_{2}$ [26-28]. $\mathrm{E}_{2}$ can be metabolised by the CYP1A1 and CYP1B1 enzymes to catechol oestrogens, 2-hydroxyestradiol (2-HE) and 4-hydroxyestradiol (4-HE), which can be further metabolised to methoxyestrogens (e.g. 2-methoxyestradiol (2-ME)) via catechol-O-methyltransferase [29]. $\mathrm{E}_{2}$, acting through oestrogen receptors $\mathrm{ER} \alpha$ and $\mathrm{ER} \beta$, has both genomic and nongenomic effects [30, 31]. Genomic actions result from alteration of gene expression, such as transcription of the vascular endothelial growth factor (VEGF)-A gene [32, 33], which is mediated by binding of $\mathrm{E}_{2}$-bound nuclear receptors to the oestrogen-response element. Nongenomic activities reflect the more rapid activation of signal transduction pathways, including the phosphatidylinositol 3-kinase (PI3K)/Akt, mitogen-activated protein kinase (MAPK) and mammalian target of rapamycin (mTOR) pathways [30, 31, 34].

\section{Lung adenocarcinoma}

Lung cancer is now the leading cause of cancer-related death in females [20]. Although smoking remains the primary risk factor for lung cancer, female predominance in lung adenocarcinoma, the most common histological subtype of nonsmall cell lung cancer (NSCLC), in both smokers and nonsmokers suggests that female hormones also have a significant role in its pathogenesis [35-38]. The decrease in risk for this lung cancer subtype after menopause also supports the hypothesis that endogenous oestrogen predisposes females to the disease [39].

Oestrogen synthesis and signalling have been shown to contribute to the growth and proliferation of lung adenocarcinoma in vitro. Aromatase activity was detected in human NSCLC cell lines, primary tumour tissues and metastases [40]. The presence of aromatase enabled lung carcinoma cells to produce their own oestrogen and, thus, is linked to the poor survival rates in females [41-43]. Numerous studies have confirmed the presence of functional $\mathrm{ER} \alpha$ and $\mathrm{ER} \beta$ at nuclear and cytoplasmic sites in lung adenocarcinoma and other NSCLC cells [39, 44-48]. Interaction of ERs, progesterone receptors and growth factor signalling was suggested to contribute to clinical outcomes of lung adenocarcinoma [49]. Interaction of both genomic and nongenomic actions was proposed to promote cell growth $[48,50]$. Although the functions of the receptors remain incompletely understood, the presence of ERs, particularly ER $\beta$, in NSCLC cell lines and primary cells was associated with poor survival outcomes for lung adenocarcinoma in both sexes [42, 51-54].

Growth and proliferation in vitro of human NSCLC cell lines and primary lung adenocarcinoma cells were enhanced by oestrogen-stimulated gene expression in a receptor-dependent manner $[48,55-58]$. In vitro, $\mathrm{ER} \alpha$ or ER $\beta$ levels were correlated with increased NSCLC proliferation [56, 59]. Proliferation of normal lung fibroblasts and lung tumour cells in vitro was similarly induced by oestrogen in a dose-dependent manner [60]. Oestrogen accelerated growth of lung adenocarcinoma xenografts in mice through increased VEGF secretion and angiogenesis [61]. Oestrogen-promoted tumour progression in a mouse model of lung adenocarcinoma induced with $K$-ras oncogene activation and $p 53$ tumour suppressor gene deletion has been reported [62]. In that study, pharmacological administration of oestrogen had increased the number of tumours and tumour volume, whereas tumour development patterns were similar in ovariectomised female and male mice, consistent with the regulation of tumour progression by endogenous oestrogen [62].

A greater incidence of lung cancer-related death in female than male double-mutant K-ras and p53 mice strongly suggests that oestrogen may also contribute to lung metastasis [63]. Oestrogen facilitates lung metastasis by affecting tumour cells in the circulation, as well as by modulating host factors, i.e. angiogenesis, vascular permeability and stromal effects [64]. The ER antagonist tamoxifen was shown to decrease the expression of matrix metalloproteinase (MMP)- 9 and thus the metastatic capability of ERpositive NSCLC cell lines [65]. Further details of anti-oestrogen treatment studies are discussed below. Although the effects of oestrogen on metastasis of lung adenocarcinoma are not completely understood, the findings mentioned above are consistent with stimulatory roles of oestrogen on the pathogenesis of lung adenocarcinoma.

KATO et al. [66] reported a murine model of lung adenocarcinoma that resulted from post-translational protein modification by ADP-ribosylation, a reaction in which the ADP-ribose moiety of nicotinamide adenine dinucleotide $\left(\mathrm{NAD}^{+}\right.$) is transferred to an acceptor (fig. 2). Bacterial toxins, including Pseudomonas aeruginosa cytotoxins and pertussis toxins [67], employ ADP-ribosylation to disrupt normal cellular metabolic or biosynthetic pathways. Human and other mammalian tissues use ADP-ribosylation to control metabolic, biosynthetic and regulatory pathways [67, 68]. ADP-ribosyltransferases catalyse the modification of acceptors [69-71], and hydrolases cleave the ADP-ribose-acceptor bond [72-76]. ADP-ribosylarginine 
FIGURE 2 The mono-ADPribosylation cycle, and the enzyme activities of ADP-ribosyltransferase (ART) $[69,70]$ and ADP-ribosyl hydrolases (ARH) $[66,72,73]$. ARTs are responsible for transferring the ADP-ribose moiety from nicotinamide adenine dinucleotide $\left(\mathrm{NAD}^{+}\right)$to an acceptor amino acid. ARH catalyses the hydrolysis of the bound ADP-ribose protein bond resulting in the regeneration of free protein.

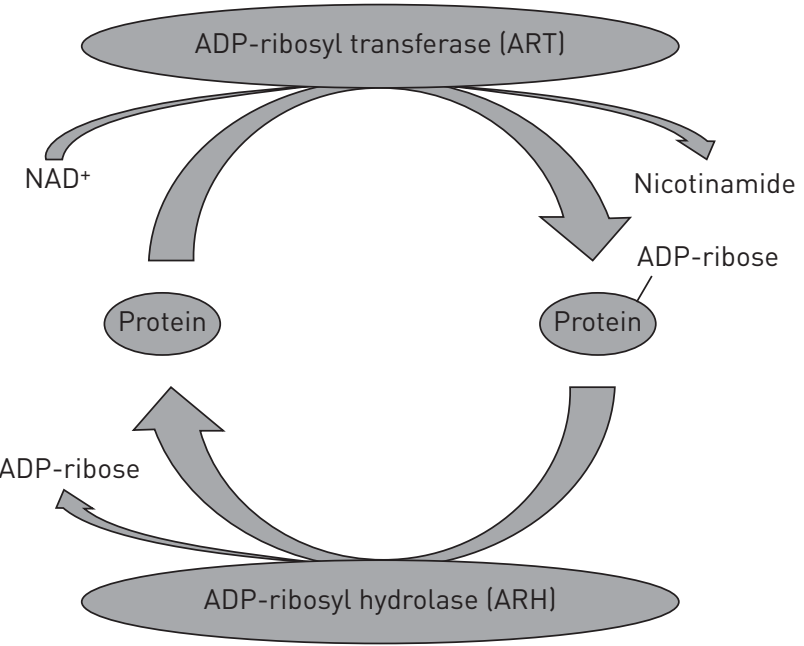

hydrolase (ARH1) reverses the ADP-ribosylation of arginine by cleaving the ADP-ribose-(arginine) protein bond to restore the native protein $[75,76] . A R H 1^{+/-}$and $A R H 1^{-/-}$mice developed greater numbers of lung adenocarcinomas than $A R H 1^{+/+}$wild-types. Moreover, ARH1-deficient cells in culture exhibited higher proliferation rates and larger numbers of colonies than their wild-type counterparts. Tumorigenesis appears due to loss of the functioning ARH1 allele. The occurrence of adenocarcinoma in heterozygous mice with loss of the functioning allele leads to the conclusion that ARH1 is a tumour suppressor gene and, thus, plays a critical role in progression of lung adenocarcinoma.

To assess the effects of oestrogen on this murine model of lung adenocarcinoma, five sex groups were compared. Female-equivalent mice comprised female, female ovariectomised treated with oestrogen and male plus oestrogen mice, whereas male-equivalent mice were male and female ovariectomised mice. Mouse embryonic fibroblasts grown from wild-type, heterozygous (+/-), and homozygous (-/-) ARH1 mice were injected intravenously or subcutaneously into all groups. Tumour growth in female-equivalent mice was more rapid than in male-equivalent counterparts, clearly consistent with a role of endogenous oestrogen in tumorigenesis. Moreover, tumour growth rate in female ovariectomised mice was similar to that of male mice. Oestrogen administration further enhanced tumour growth rates, suggesting that oestrogen levels might be directly correlated with the pathogenesis of lung adenocarcinoma.

\section{LAM and BML}

LAM is a rare multisystem disease characterised by cystic lung destruction, pleural and/or ascitic chylous effusions, and renal angiomyolipomas (AMLs) [1, 77-81]. Cystic lung destruction results from the growth and proliferation of abnormal smooth muscle-like LAM cells. LAM occurs almost exclusively in females either sporadically or in association with tuberous sclerosis complex (TSC) [81], an autosomal-dominant genetic disorder caused by mutations in either the TSC1 or TSC2 tumour suppressor genes [82, 83]. In response to extracellular factors (e.g. nutrients, hormones, hypoxia), the protein products of two TSC genes form a TSC1-TSC2 heterodimer, which modulates activation of the mTOR pathway [84]. mTOR is the master regulator of cell-cycle progression, growth and proliferation via phosphorylation of ribosomal protein S6 and 4E-BP1, making it a therapeutic target in many cancers and tumour-related diseases [85-88].

$\mathrm{BML}$ is a rare disease that appears to result from the benign metastasis of smooth muscle cells to the lung [89]. Despite the inherent aetiology in its name, BML is poorly understood with several hypotheses proposed to describe its multifocal proliferative properties and metastatic potential $[2,89,90]$. Behaviour of LAM cells is similar to that of lung cancer in terms of growth, proliferation, cell survival in the circulation, and metastasis [91-93]. Striking patho-physiological similarities between LAM and BML have enabled researchers to correlate findings in models of either disease and clinical observations in patients with LAM or BML $[94,95]$. The evident female predominance among patients, together with correlation of clinical lesion grades with hormonal levels at menarche, pregnancy, menstruation and menopause, are all consistent with the hypothesis that oestrogen contributes to progression of LAM as well as BML $[2,80,96]$.

The observations that both ERs were found in the affected lungs, LAM cells and uterine leiomyoma of BML are consistent with a receptor-dependent model of progression of these diseases [2, 97-99]. Aromatase 
presence and activity in either disease has not been described, although there are clinical reports of the use of the aromatase inhibitor letrozole as a treatment for BML $[96,100]$. Among other reports of effects of female hormones on cell growth and proliferation in LAM models, in vitro studies of TSC2-null Eker rat embryonic fibroblasts revealed that prolactin, regulated by oestrogen [101], an important reproductive hormone, increased proliferation via activation of MAPK and other protein kinase pathways [102]. Observations on the proliferative effects of oestrogen using Eker rat uterine leiomyoma-derived smooth muscle cells (ELT3) in vitro were similar [103], as were findings with primary cultures of human AML cells on genomic and nongenomic effects of oestrogen [104].

To explore the hypothesis that oestrogen induces changes in cell size as well as proliferation in cells grown from skin of TSC-LAM patients, we measured rat and human cells with different methodologies (fig. 3). In preliminary experiments with rat and human fibroblasts lacking TSC2, sirolimus decreased cell size and $\mathrm{E}_{2}$ treatment increased it. $\mathrm{E}_{2}$ also increased proliferation of both human TSC2-heterozygous and TSC2-null LAM cells. Moreover, $\mathrm{E}_{2}$ effects on cell size and number were prevented by MAPK kinase (MEK) $1 / 2$ inhibitors. These observations may offer clues to the elucidation of biochemical mechanisms that regulate cell size and proliferation, including effects of oestrogen on mTOR and other signalling pathways, and perhaps an insight into potential therapeutic targets for anti-oestrogen treatments.

Growth of TSC2-null human AML cells in vitro and pulmonary metastasis of TSC2-null Eker rat lymphoma cells (ELT3) in mice were stimulated by oestrogen via both genomic transcription-dependent and nongenomic MAPK-dependent pathways [105]. These findings were consistent with other in vitro and in vivo observations using rat LAM-TSC models [106, 107]. Moreover, inhibiting MEK1/2 with CI-1040 also interfered with the survival and growth of TSC2-null cells in mice [105]. A recent study describes a novel TSC-LAM murine model, which was generated by intratracheal instillation of TSC2-deficient, patientderived AML cells, for monitoring systemic tumorigenesis, dissemination and drug responses in real-time using single photon emission computed tomography/computed tomography, providing potential preclinical drug-testing options [108]. Oestrogen accelerated the growth of immortalised AML cells via the activation of Akt and downstream signalling pathways in a mouse xenograft model [109].

We also studied the effects of oestrogen on murine models of LAM and BML. We established the five sex groups, i.e. three female equivalent and two male equivalent, as described for the ARH1 mouse models. We injected patient-derived LAM or BML cells either subcutaneously or intravenously and measured, respectively, local tumour growth or growth of metastases in lung and other organs. Preliminary data showed that tumour growth was more rapid in female-equivalent than male-equivalent mice. Furthermore, pharmacological oestrogen treatment resulted in rates of growth that exceeded those observed in female mice. These data are clearly consistent with contributions of endogenous oestrogen to tumorigenesis. Additional studies are required to clarify other effects of oestrogen on mechanisms of disease pathogenesis.

Despite their apparently benign morphology, LAM cells exhibit metastatic behaviours that can be attributed to the modified actin cytoskeleton that results from impaired TSC1 and/or TSC2 function and downstream activation of mTOR [84]. Chemotactic migration of TSC2-null cells was enhanced, whereas cell adhesion and Rho activity were decreased [110]. Overexpression of TSC1 (hamartin) increased Rho activity, focal adhesion and stress fibre formation [111]. MMP-2 activity, an indicator of tumour cell invasiveness or metastatic capability, was increased by ER activation in spindle-shaped LAM cells, consistent with clinical observations of MMP activation in patients with LAM [112, 113]. Lymphatic involvement in tumour cell dissemination and metastasis has also been documented [114, 115]. Oestrogen was shown to promote

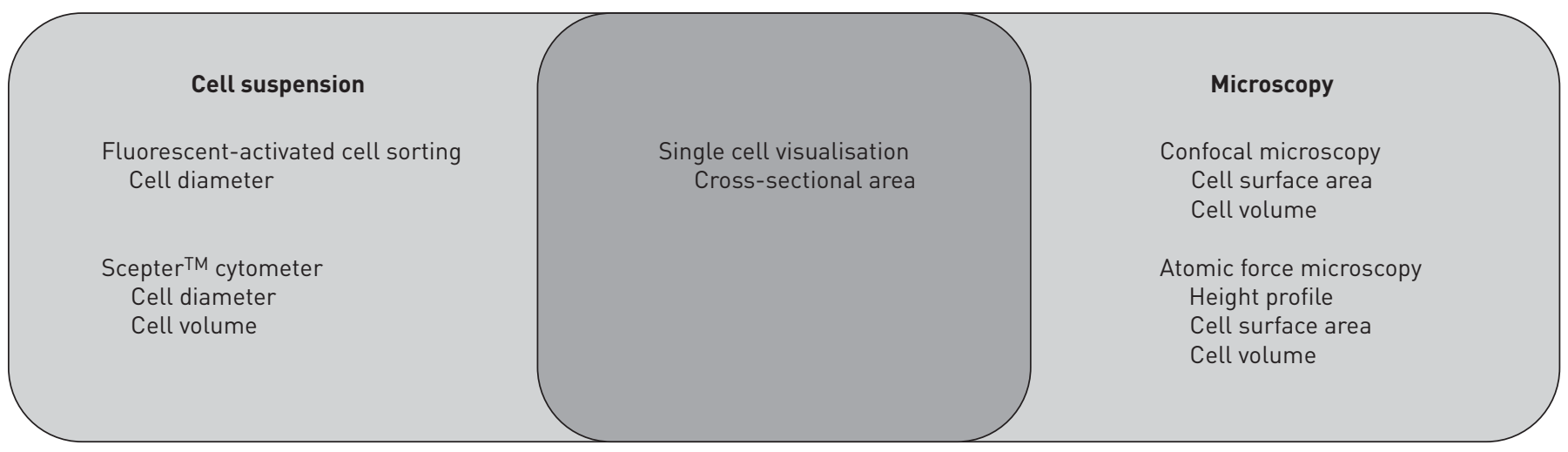

FIGURE 3 Venn diagram summarising the various laboratory methods for measuring cell size and the size parameters acquired by each method. 
pulmonary metastases using the ELT3 $\left(\mathrm{TSC}^{-/-}\right.$) uterine leiomyoma cells, although whether or not effects of oestrogen and the hamartin-tuberin complex are related remains unknown.

\section{Pulmonary fibrosis}

Idiopathic pulmonary fibrosis has been implicated as a male-predominant disease. However, the role of oestrogen in this disease has not been clearly elucidated. The finding that pulmonary fibrosis is prevalent in males leads to the proposal that oestrogen could have protective effects. The results of some of the animal models are controversial but it has been shown that oestrogens could have protective effects for the development of pulmonary fibrosis [116-118]. Interestingly, the severity of pulmonary fibrosis also appears to depend on sex [119-122]. While the majority of these findings support a protective role of oestrogen in experimental pulmonary fibrosis, further studies are warranted.

\section{Therapeutic studies of oestrogen in lung diseases}

Numerous, albeit diverse, effects of oestrogen on progression of lung diseases led to speculation about the potential efficacy of anti-oestrogen therapies that target key regulators of oestrogen synthesis and signalling, e.g. aromatase and ERs, respectively (table 2). Aromatase inhibitors such as letrozole inhibit enzymatic production and thereby lower oestrogen levels [123]. Oestrogen-receptor downregulators and selective oestrogen-receptor modulators bind specifically to ERs to alter their activity and signalling [124].

Effects of anti-oestrogens on progression of the lung diseases discussed here have been studied using cell culture and animal models. Sizes of lung adenocarcinoma xenografts were significantly smaller after cells were administered with, rather than without, the aromatase inhibitor anastrozole [40]. ER antagonist tamoxifen decreased the extent of metastatic spread of cultured ER-positive NSCLC cells [65]. Combined treatment with tamoxifen and gefitinib, an epidermal growth factor receptor tyrosine kinase inhibitor, decreased proliferation and increased apoptosis of lung adenocarcinoma cell lines [125].

Sirolimus, the presently favoured treatment for LAM, directly inhibits mTOR activity, thus, slowing disease progression. Clinical trials showing that sizes of AML tumour were partially restored after withdrawal of sirolimus [126] prompted investigation of other therapeutic options, e.g. anti-oestrogen agents, together with or without sirolimus $[126,127]$. Tamoxifen reduced VEGF levels in $\mathrm{Tscl}^{+/-}$mice and reduced the development of female $\mathrm{Tscl}^{+/-}$mouse liver haemangiomas, tumours that are related to renal AMLs and LAM cells [128]. Tamoxifen was also shown to accelerate the growth of AML cells, which differs from its effect on the $\mathrm{Tscl}^{+/-}$mouse liver haemangiomas [104]. In a recent paper, LI et al. [129] reported that ER antagonist faslodex decreased tumour size by inhibiting oestrogen-induced ECM remodelling, expression of MMP-2 and metastasis to the lung. Such effects of anti-oestrogen agents on lung diseases in model systems are certainly cause for optimism, albeit still incomplete. Further investigation should help us to better understand their potential therapeutic value.

\section{Conclusion}

Based on our findings, as well as those from literature summarised in this review, oestrogen plays a significant role in the pathogenesis of predominantly female lung diseases. There is also evidence that oestrogen may have variable effects on other lung diseases, including those that are predominantly found in males. Oestrogen is probably not the only sex hormone that influences lung disease incidence, severity and/ or pathogenesis, nor does it necessarily promote disease progression. Rather, the complex interactions between multiple hormones, receptors and/or signalling pathways probably influence sex predominance and the defining characteristics of lung diseases. Additional investigation of sex differences using cultured cells and animal models may provide valuable information on the association between lung

TABLE 2 Types of anti-oestrogen therapy

\section{Aromatase inhibitor \\ Oestrogen receptor downregulator}

Selective oestrogen receptor modulator
Blocks the enzymatic activity of aromatase and inhibits $17 \beta$-oestradiol $\left(E_{2}\right)$ synthesis

Binds directly to oestrogen receptors and thus inhibits oestrogen binding

Reduces number of oestrogen receptors

Alters the shape or conformation of oestrogen receptors

Selectively binds to oestrogen receptors and thus inhibits oestrogen binding
Letrozole, anastrozole, exemestane

Fulvestrant

Tamoxifen, raloxifene, toremifene 
pathophysiology and endocrine factors. Studies of anti-oestrogen and other anti-hormonal treatments may ultimately improve therapeutic options for patients with lung diseases.

\section{References}

1 Ryu JH, Moss J, Beck GJ, et al. The NHLBI lymphangioleiomyomatosis registry: characteristics of 230 patients at enrollment. Am J Respir Crit Care Med 2006; 173: 105-111.

2 Pitts S, Oberstein EM, Glassberg MK. Benign metastasizing leiomyoma and lymphangioleiomyomatosis: sexspecific diseases? Clin Chest Med 2004; 25: 343-360.

Muscat JE, Wynder EL. Lung cancer pathology in smokers, ex-smokers and never smokers. Cancer Lett 1995; 88: 1-5. Badesch DB, Raskob GE, Elliott CG, et al. Pulmonary arterial hypertension: baseline characteristics from the REVEAL Registry. Chest 2010; 137: 376-387.

5 Cottin V, Cordier JF. Combined pulmonary fibrosis and emphysema in connective tissue disease. Curr Opin Pulm Med 2012; 18: 418-427.

6 Gribbin J, Hubbard RB, Le Jeune I, et al. Incidence and mortality of idiopathic pulmonary fibrosis and sarcoidosis in the UK. Thorax 2006; 61: 980-985.

7 Baumgartner KB, Samet JM, Stidley CA, et al. Cigarette smoking: a risk factor for idiopathic pulmonary fibrosis. Am J Respir Crit Care Med 1997; 155: 242-248.

8 Kornum JB, Christensen S, Grijota M, et al. The incidence of interstitial lung disease 1995-2005: a Danish nationwide population-based study. BMC Pulm Med 2008; 8: 24.

9 Coultas DB, Zumwalt RE, Black WC, et al. The epidemiology of interstitial lung diseases. Am J Respir Crit Care Med 1994; 150: 967-972.

10 Vassallo R, Ryu JH, Schroeder DR, et al. Clinical outcomes of pulmonary Langerhans'-cell histiocytosis in adults. N Engl J Med 2002; 346: 484-490.

11 Travis WD, Hunninghake G, King TE Jr, et al. Idiopathic nonspecific interstitial pneumonia: report of an American Thoracic Society project. Am J Respir Crit Care Med 2008; 177: 1338-1347.

12 Portnoy J, Veraldi KL, Schwarz MI, et al. Respiratory bronchiolitis-interstitial lung disease: long-term outcome. Chest 2007; 131: 664-671.

13 de Marco R, Locatelli F, Sunyer J, et al. Differences in incidence of reported asthma related to age in men and women. A retrospective analysis of the data of the European Respiratory Health Survey. Am J Respir Crit Care Med 2000; $162: 68-74$.

14 Choi IS. Gender-specific asthma treatment. Allergy Asthma Imunol Res 2011; 3: 74-80.

15 Leynaert B, Sunyer J, Garcia-Esteban R, et al. Gender differences in prevalence, diagnosis and incidence of allergic and non-allergic asthma: a population-based cohort. Thorax 2012; 67: 625-631.

16 Akinbami LJ, Liu X. Chronic obstructive pulmonary disease among adults aged 18 and over in the United States, 1998-2009. NCHS Data Brief 2011; 1-8.

17 Aryal S, Diaz-Guzman E, Mannino DM. COPD and gender differences: an update. Transl Res 2013 [Epub ahead of print DOI: $10.1016 / j . t r s l .2013 .04 .003]$

18 Cote CG, Chapman KR. Diagnosis and treatment considerations for women with COPD. Int J Clin Pract 2009; 63: 486-493.

19 Townsend EA, Miller VM, Prakash YS. Sex differences and sex steroids in lung health and disease. Endocr Rev 2012; 33: $1-47$.

20 Jemal A, Siegel R, Xu J, et al. Cancer statistics, 2010. CA Cancer J Clin 2010; 60: 277-300.

21 Schiavina M, Di Scioscio V, Contini P, et al. Pulmonary lymphangioleiomyomatosis in a karyotypically normal man without tuberous sclerosis complex. Am J Respir Crit Care Med 2007; 176: 96-98.

22 Ryu JH, Sykes AM, Lee AS, et al. Cystic lung disease is not uncommon in men with tuberous sclerosis complex. Respir Med 2012; 106: 1586-1590.

23 Henderson BE, Feigelson HS. Hormonal carcinogenesis. Carcinogenesis 2000; 21: 427-433.

24 Deroo BJ, Korach KS. Estrogen receptors and human disease. J Clin Invest 2006; 116: 561-570.

25 Miller WL, Auchus RJ. The molecular biology, biochemistry, and physiology of human steroidogenesis and its disorders. Endocr Rev 2011; 32: 81-151.

26 Di Nardo G, Gilardi G. Human aromatase: perspectives in biochemistry and biotechnology. Biotechnol Appl Biochem 2013; 60: 92-101.

27 Simpson ER, Mahendroo MS, Means GD, et al. Aromatase cytochrome P450, the enzyme responsible for estrogen biosynthesis. Endocr Rev 1994; 15: 342-355.

28 Ghosh D, Griswold J, Erman M, et al. Structural basis for androgen specificity and oestrogen synthesis in human aromatase. Nature 2009; 457: 219-223.

29 Parl FF, Dawling S, Roodi N, et al. Estrogen metabolism and breast cancer: a risk model. Ann N Y Acad Sci 2009; 1155: 68-75.

30 Hall JM, Couse JF, Korach KS. The multifaceted mechanisms of estradiol and estrogen receptor signaling. J Biol Chem 2001; 276: 36869-36872.

31 Losel R, Wehling M. Nongenomic actions of steroid hormones. Nat Rev Mol Cell Biol 2003; 4: 46-56.

32 Mueller MD, Vigne JL, Minchenko A, et al. Regulation of vascular endothelial growth factor (VEGF) gene transcription by estrogen receptors alpha and beta. Proc Natl Acad Sci USA 2000; 97: 10972-10977.

33 Stoner M, Wormke M, Saville B, et al. Estrogen regulation of vascular endothelial growth factor gene expression in ZR75 breast cancer cells through interaction of estrogen receptor alpha and SP proteins. Oncogene 2004; 23: 1052-1063.

34 Pedram A, Razandi M, Aitkenhead M, et al. Integration of the non-genomic and genomic actions of estrogen. Membrane-initiated signaling by steroid to transcription and cell biology. J Biol Chem 2002; 277: 50768-50775. Subramanian J, Govindan R. Lung cancer in never smokers: a review. J Clin Oncol 2007; 25: 561-570.

Travis WD, Travis LB, Devesa SS. Lung cancer. Cancer 1995; 75: 191-202.

Wakelee HA, Chang ET, Gomez SL, et al. Lung cancer incidence in never smokers. J Clin Oncol 2007; 25: 472-478. Jemal A, Ward E, Thun M. Declining death rates reflect progress against cancer. PLoS One 2010; 5: e9584.

Taioli E, Wynder EL. Re: Endocrine factors and adenocarcinoma of the lung in women. J Natl Cancer Inst 1994; 86: $869-870$. 
40 Marquez-Garban DC, Chen HW, Goodglick L, et al. Targeting aromatase and estrogen signaling in human nonsmall cell lung cancer. Ann N Y Acad Sci 2009; 1155: 194-205.

41 Weinberg OK, Marquez-Garban DC, Fishbein MC, et al. Aromatase inhibitors in human lung cancer therapy. Cancer Res 2005; 65: 11287-11291.

42 Stabile LP, Davis AL, Gubish CT, et al. Human non-small cell lung tumors and cells derived from normal lung express both estrogen receptor alpha and beta and show biological responses to estrogen. Cancer Res 2002; 62: 2141-2150.

43 Mah V, Seligson DB, Li A, et al. Aromatase expression predicts survival in women with early-stage non small cell lung cancer. Cancer Res 2007; 67: 10484-10490.

44 Beattie CW, Hansen NW, Thomas PA. Steroid receptors in human lung cancer. Cancer Res 1985; 45 : $4206-4214$.

45 Marquez-Garban DC, Mah V, Alavi M, et al. Progesterone and estrogen receptor expression and activity in human non-small cell lung cancer. Steroids 2011; 76: 910-920.

46 Mollerup S, Jorgensen K, Berge G, et al. Expression of estrogen receptors alpha and beta in human lung tissue and cell lines. Lung Cancer 2002; 37: 153-159.

47 Niikawa H, Suzuki T, Miki Y, et al. Intratumoral estrogens and estrogen receptors in human non-small cell lung carcinoma. Clin Cancer Res 2008; 14: 4417-4426.

48 Pietras RJ, Marquez DC, Chen HW, et al. Estrogen and growth factor receptor interactions in human breast and non-small cell lung cancer cells. Steroids 2005; 70: 372-381.

49 Stabile LP, Dacic S, Land SR, et al. Combined analysis of estrogen receptor beta-1 and progesterone receptor expression identifies lung cancer patients with poor outcome. Clin Cancer Res 2011; 17: 154-164.

50 Gruber CJ, Tschugguel W, Schneeberger C, et al. Production and actions of estrogens. N Engl J Med 2002; 346: 340-352.

51 Kawai H, Ishii A, Washiya K, et al. Combined overexpression of EGFR and estrogen receptor alpha correlates with a poor outcome in lung cancer. Anticancer Res 2005; 25: 4693-4698.

52 Schwartz AG, Prysak GM, Murphy V, et al. Nuclear estrogen receptor beta in lung cancer: expression and survival differences by sex. Clin Cancer Res 2005; 11: 7280-7287.

53 Skov BG, Fischer BM, Pappot H. Oestrogen receptor beta over expression in males with non-small cell lung cancer is associated with better survival. Lung Cancer 2008; 59: 88-94.

54 Wu CT, Chang YL, Shih JY, et al. The significance of estrogen receptor beta in 301 surgically treated non-small cell lung cancers. J Thorac Cardiovasc Surg 2005; 130: 979-986.

55 Dougherty SM, Mazhawidza W, Bohn AR, et al. Gender difference in the activity but not expression of estrogen receptors alpha and beta in human lung adenocarcinoma cells. Endocr Relat Cancer 2006; 13: 113-134.

56 Hershberger PA, Vasquez AC, Kanterewicz B, et al. Regulation of endogenous gene expression in human non-small cell lung cancer cells by estrogen receptor ligands. Cancer Res 2005; 65: 1598-1605.

57 Kato S, Endoh H, Masuhiro Y, et al. Activation of the estrogen receptor through phosphorylation by mitogenactivated protein kinase. Science 1995; 270: 1491-1494.

58 Stabile LP, Lyker JS, Gubish CT, et al. Combined targeting of the estrogen receptor and the epidermal growth factor receptor in non-small cell lung cancer shows enhanced antiproliferative effects. Cancer Res 2005; 65: 1459-1470.

59 Marquez-Garban DC, Chen HW, Fishbein MC, et al. Estrogen receptor signaling pathways in human non-small cell lung cancer. Steroids 2007; 72: 135-143.

60 Stabile LP, Siegfried JM. Estrogen receptor pathways in lung cancer. Curr Oncol Rep 2004; 6: $259-267$.

61 Jarzynka MJ, Guo P, Bar-Joseph I, et al. Estradiol and nicotine exposure enhances A549 bronchioloalveolar carcinoma xenograft growth in mice through the stimulation of angiogenesis. Int J Oncol 2006; 28: 337-344.

62 Hammoud Z, Tan B, Badve S, et al. Estrogen promotes tumor progression in a genetically defined mouse model of lung adenocarcinoma. Endocr Relat Cancer 2008; 15: 475-483.

63 Zheng S, El-Naggar AK, Kim ES, et al. A genetic mouse model for metastatic lung cancer with gender differences in survival. Oncogene 2007; 26: 6896-6904.

64 Banka CL, Lund CV, Nguyen MT, et al. Estrogen induces lung metastasis through a host compartment-specific response. Cancer Res 2006; 66: 3667-3672.

65 Wang XY, Wang Y, Liu HC. Tamoxifen lowers the MMP-9/TIMP-1 ratio and inhibits the invasion capacity of ERpositive non-small cell lung cancer cells. Biomed Pharmacother 2011; 65: 525-528.

66 Kato J, Zhu J, Liu C, et al. ADP-ribosylarginine hydrolase regulates cell proliferation and tumorigenesis. Cancer Res 2011; 71: 5327-5335.

67 Moss J, Vaughan M, eds. ADP-ribosylating Toxins and G Proteins: Insights into Signal Transduction. Washington, American Society for Microbiology Press, 1990.

68 Williamson KC, Moss J. Mono-ADP-ribosyltransferases and ADP-ribosylarginine hydrolase: a mono-ADPribosylation cycle in animal cells. In: Moss J, Vaughan M, eds. ADP-ribosylating Toxins and G Proteins: Insights into Signal Transduction. Washington, American Society for Microbiology Press, 1990; pp. 493-510.

69 Okazaki IJ, Moss J. Glycosylphosphatidylinositol-anchored and secretory isoforms of mono-ADP-ribosyltransferases. J Biol Chem 1998; 273: 23617-23620.

70 Okazaki IJ, Moss J. Characterization of glycosylphosphatidylinositiol-anchored, secreted, and intracellular vertebrate mono-ADP-ribosyltransferases. Annu Rev Nutr 1999; 19: 485-509.

71 Zolkiewska A, Moss J. Integrin alpha 7 as substrate for a glycosylphosphatidylinositol-anchored ADPribosyltransferase on the surface of skeletal muscle cells. J Biol Chem 1993; 268: 25273-25276.

72 Oka S, Kato J, Moss J. Identification and characterization of a mammalian 39-kDa poly(ADP-ribose) glycohydrolase. J Biol Chem 2006; 281: 705-713.

73 Ono T, Kasamatsu A, Oka S, et al. The 39-kDa poly(ADP-ribose) glycohydrolase ARH3 hydrolyzes O-acetyl-ADPribose, a product of the Sir2 family of acetyl-histone deacetylases. Proc Natl Acad Sci USA 2006; 103: 16687-16691.

74 Kasamatsu A, Nakao M, Smith BC, et al. Hydrolysis of O-acetyl-ADP-ribose isomers by ADP-ribosylhydrolase 3. J Biol Chem 2011; 286: 21110-21117.

75 Moss J, Jacobson MK, Stanley SJ. Reversibility of arginine-specific mono(ADP-ribosyl)ation: identification in erythrocytes of an ADP-ribose-L-arginine cleavage enzyme. Proc Natl Acad Sci USA 1985; 82: 5603-5607.

76 Moss J, Stanley SJ, Nightingale MS, et al. Molecular and immunological characterization of ADP-ribosylarginine hydrolases. J Biol Chem 1992; 267: 10481-10488. 
Kitaichi M, Nishimura K, Itoh H, et al. Pulmonary lymphangioleiomyomatosis: a report of 46 patients including a clinicopathologic study of prognostic factors. Am J Respir Crit Care Med 1995; 151: 527-533.

78 Chu SC, Horiba K, Usuki J, et al. Comprehensive evaluation of 35 patients with lymphangioleiomyomatosis. Chest 1999; 115: 1041-1052.

79 Urban T, Lazor R, Lacronique J, et al. Pulmonary lymphangioleiomyomatosis. A study of 69 patients. Groupe d'Etudes et de Recherche sur les Maladies "Orphelines" Pulmonaires (GERM"O"P). Medicine (Baltimore) 1999; 78: 321-337.

80 Johnson SR, Tattersfield AE. Clinical experience of lymphangioleiomyomatosis in the UK. Thorax 2000; 55 : $1052-1057$.

81 Taveira-Da Silva AM, Pacheco-Rodriguez G, Moss J. The natural history of lymphangioleiomyomatosis: markers of severity, rate of progression and prognosis. Lymphat Res Biol 2010; 8: 9-19.

82 Costello LC, Hartman TE, Ryu JH. High frequency of pulmonary lymphangioleiomyomatosis in women with tuberous sclerosis complex. Mayo Clin Proc 2000; 75: 591-594.

83 Crino PB, Nathanson KL, Henske EP. The tuberous sclerosis complex. N Engl J Med 2006; 355: $1345-1356$.

84 Huang J, Manning BD. The TSC1-TSC2 complex: a molecular switchboard controlling cell growth. Biochem J2008; 412: 179-190.

85 Goncharova EA, Goncharov DA, Eszterhas A, et al. Tuberin regulates p70 S6 kinase activation and ribosomal protein S6 phosphorylation. A role for the TSC2 tumor suppressor gene in pulmonary lymphangioleiomyomatosis (LAM). J Biol Chem 2002; 277: 30958-30967.

86 Ruvinsky I, Sharon N, Lerer T, et al. Ribosomal protein S6 phosphorylation is a determinant of cell size and glucose homeostasis. Genes Dev 2005; 19: 2199-2211.

87 Fingar DC, Salama S, Tsou C, et al. Mammalian cell size is controlled by mTOR and its downstream targets S6K1 and 4EBP1/eIF4E. Genes Dev 2002; 16: 1472-1487.

88 Sabatini DM. mTOR and cancer: insights into a complex relationship. Nat Rev Cancer 2006; 6: 729-734.

89 Kayser K, Zink S, Schneider T, et al. Benign metastasizing leiomyoma of the uterus: documentation of clinical, immunohistochemical and lectin-histochemical data of ten cases. Virchows Arch 2000; 437: $284-292$.

90 Esteban JM, Allen WM, Schaerf RH. Benign metastasizing leiomyoma of the uterus: histologic and immunohistochemical characterization of primary and metastatic lesions. Arch Pathol Lab Med 1999; 123: 960-962. Henske EP, McCormack FX. Lymphangioleiomyomatosis - a wolf in sheep's clothing. J Clin Invest 2012; 122: $3807-3816$.

92 Crooks DM, Pacheco-Rodriguez G, De Castro RM, et al. Molecular and genetic analysis of disseminated neoplastic cells in lymphangioleiomyomatosis. Proc Natl Acad Sci USA 2004; 101: 17462-17467.

93 Darling TN, Pacheco-Rodriguez G, Gorio A, et al. Lymphangioleiomyomatosis and TSC2-/- cells. Lymphat Res Biol 2010; 8: 59-69.

94 Taveira-Da Silva AM, Alford CE, Levens ED, et al. Favorable response to antigonadal therapy for a benign metastasizing leiomyoma. Obstet Gynecol 2012; 119: 438-442.

95 Banner AS, Carrington CB, Emory WB, et al. Efficacy of oophorectomy in lymphangioleiomyomatosis and benign metastasizing leiomyoma. N Engl J Med 1981; 305: 204-209.

96 Lewis EI, Chason RJ, Decherney AH, et al. Novel hormone treatment of benign metastasizing leiomyoma: an analysis of five cases and literature review. Fertil Steril 2013; 99: 2017-2024.

97 Logginidou H, Ao X, Russo I, et al. Frequent estrogen and progesterone receptor immunoreactivity in renal angiomyolipomas from women with pulmonary lymphangioleiomyomatosis. Chest 2000; 117: 25-30.

98 Patton KT, Cheng L, Papavero V, et al. Benign metastasizing leiomyoma: clonality, telomere length and clinicopathologic analysis. Mod Pathol 2006; 19: 130-140.

99 Jautzke G, Muller-Ruchholtz E, Thalmann U. Immunohistological detection of estrogen and progesterone receptors in multiple and well differentiated leiomyomatous lung tumors in women with uterine leiomyomas (so-called benign metastasizing leiomyomas). A report on 5 cases. Pathol Res Pract 1996; 192: 215-223.

100 Yoon G, Kim TJ, Sung CO, et al. Benign metastasizing leiomyoma with multiple lymph node metastasis: a case report. Cancer Res Treat 2011; 43: 131-133.

101 Maurer RA. Estradiol regulates the transcription of the prolactin gene. J Biol Chem 1982; 257: 2133-2136.

102 Terasaki Y, Yahiro K, Pacheco-Rodriguez G, et al. Effects of prolactin on TSC2-null Eker rat cells and in pulmonary lymphangioleiomyomatosis. Am J Respir Crit Care Med 2010; 182: 531-539.

103 Howe SR, Gottardis MM, Everitt JI, et al. Estrogen stimulation and tamoxifen inhibition of leiomyoma cell growth in vitro and in vivo. Endocrinology 1995; 136: 4996-5003.

$104 \mathrm{Yu}$ J, Astrinidis A, Howard S, et al. Estradiol and tamoxifen stimulate LAM-associated angiomyolipoma cell growth and activate both genomic and nongenomic signaling pathways. Am J Physiol Lung Cell Mol Physiol 2004; 286: L694-L700.

105 Yu JJ, Robb VA, Morrison TA, et al. Estrogen promotes the survival and pulmonary metastasis of tuberin-null cells. Proc Natl Acad Sci USA 2009; 106: 2635-2640.

106 Hodges LC, Hunter DS, Bergerson JS, et al. An in vivo/in vitro model to assess endocrine disrupting activity of xenoestrogens in uterine leiomyoma. Ann N Y Acad Sci 2001; 948: 100-111.

107 Hunter DS, Hodges LC, Eagon PK, et al. Influence of exogenous estrogen receptor ligands on uterine leiomyoma: evidence from an in vitro/in vivo animal model for uterine fibroids. Environ Health Perspect 2000; 108: Suppl. 5 829-834

108 Liu F, Lunsford EP, Tong J, et al. Real-time monitoring of tumorigenesis, dissemination, and drug response in a preclinical model of lymphangioleiomyomatosis/tuberous sclerosis complex. PLoS One 2012; 7: e38589.

109 Clements D, Asprey SL, McCulloch TA, et al. Analysis of the oestrogen response in an angiomyolipoma derived xenograft model. Endocr Relat Cancer 2009; 16: 59-72.

110 Astrinidis A, Cash TP, Hunter DS, et al. Tuberin, the tuberous sclerosis complex 2 tumor suppressor gene product, regulates Rho activation, cell adhesion and migration. Oncogene 2002; 21: 8470-8476.

111 Lamb RF, Roy C, Diefenbach TJ, et al. The TSC1 tumour suppressor hamartin regulates cell adhesion through ERM proteins and the GTPase Rho. Nat Cell Biol 2000; 2: 281-287.

112 Glassberg MK, Elliot SJ, Fritz J, et al. Activation of the estrogen receptor contributes to the progression of pulmonary lymphangioleiomyomatosis via matrix metalloproteinase-induced cell invasiveness. J Clin Endocrinol Metab 2008; 93: 1625-1633. 
113 Matsui K, Takeda K, Yu ZX, et al. Role for activation of matrix metalloproteinases in the pathogenesis of pulmonary lymphangioleiomyomatosis. Arch Pathol Lab Med 2000; 124: 267-275.

114 Seyama K, Kumasaka T, Kurihara M, et al. Lymphangioleiomyomatosis: a disease involving the lymphatic system. Lymphat Res Biol 2010; 8: 21-31.

115 Glasgow CG, El-Chemaly S, Moss J. Lymphatics in lymphangioleiomyomatosis and idiopathic pulmonary fibrosis. Eur Respir Rev 2012; 21: 196-206.

116 Moore BB, Hogaboam CM. Murine models of pulmonary fibrosis. Am J Physiol Lung Cell Mol Physiol 2008; 294: L152-L160.

117 Gharaee-Kermani M, Hatano K, Nozaki Y, et al. Gender-based differences in bleomycin-induced pulmonary fibrosis. Am J Pathol 2005; 166: 1593-1606.

118 Tofovic SP, Zhang X, Jackson EK, et al. 2-methoxyestradiol attenuates bleomycin-induced pulmonary hypertension and fibrosis in estrogen-deficient rats. Vascul Pharmacol 2009; 51: 190-197.

119 Haston CK, Wang M, Dejournett RE, et al. Bleomycin hydrolase and a genetic locus within the MHC affect risk for pulmonary fibrosis in mice. Hum Mol Genet 2002; 11: 1855-1863.

120 Voltz JW, Card JW, Carey MA, et al. Male sex hormones exacerbate lung function impairment after bleomycininduced pulmonary fibrosis. Am J Respir Cell Mol Biol 2008; 39: 45-52.

121 Brass DM, McGee SP, Dunkel MK, et al. Gender influences the response to experimental silica-induced lung fibrosis in mice. Am J Physiol Lung Cell Mol Physiol 2010; 299: L664-L671.

122 Lekgabe ED, Royce SG, Hewitson TD, et al. The effects of relaxin and estrogen deficiency on collagen deposition and hypertrophy of nonreproductive organs. Endocrinology 2006; 147: 5575-5583.

123 Lipton A, Demers LM, Harvey HA, et al. Letrozole (CGS 20267). A phase I study of a new potent oral aromatase inhibitor of breast cancer. Cancer 1995; 75: 2132-2318.

124 Shang Y. Molecular mechanisms of oestrogen and SERMs in endometrial carcinogenesis. Nat Rev Cancer 2006; 6: 360-368.

125 Shen $\mathrm{H}$, Yuan $\mathrm{Y}$, Sun $\mathrm{J}$, et al. Combined tamoxifen and gefitinib in non-small cell lung cancer shows antiproliferative effects. Biomed Pharmacother 2010; 64: 88-92.

126 Bissler JJ, McCormack FX, Young LR, et al. Sirolimus for angiomyolipoma in tuberous sclerosis complex or lymphangioleiomyomatosis. N Engl J Med 2008; 358: 140-151.

127 Glasgow CG, Steagall WK, Taveira-Dasilva A, et al. Lymphangioleiomyomatosis (LAM): molecular insights lead to targeted therapies. Respir Med 2010; 104: Suppl. 1 S45-S58.

128 El-Hashemite N, Walker V, Kwiatkowski DJ. Estrogen enhances whereas tamoxifen retards development of Tsc mouse liver hemangioma: a tumor related to renal angiomyolipoma and pulmonary lymphangioleiomyomatosis. Cancer Res 2005; 65: 2474-2481.

129 Li C, Zhou X, Sun Y, et al. Faslodex inhibits estradiol-induced ECM dynamics and lung metastasis in a model of LAM. Am J Respir Cell Mol Biol 2013; 49: 132-142. 